\title{
Well-being of judges: A review of quantitative and qualitative studies
}

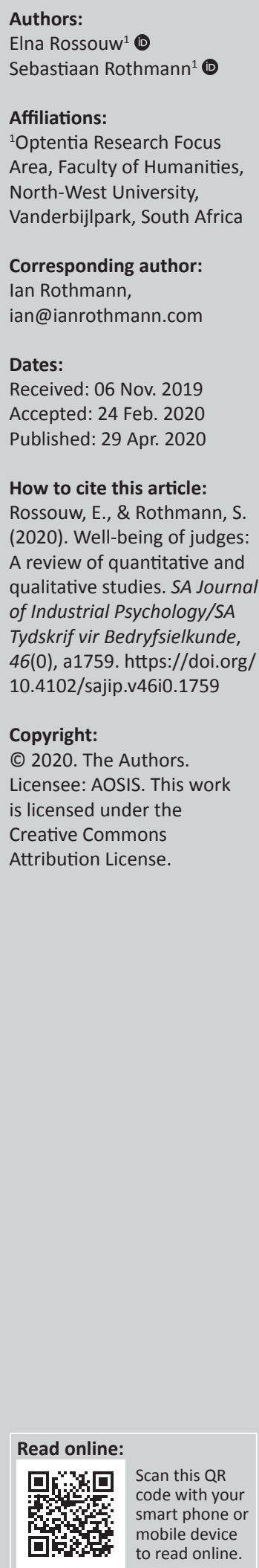

Orientation: Research regarding the well-being of judges is essential given the effects thereof on their work and contextual performance.

Research purpose: This study aimed to review qualitative and quantitative empirical studies on the well-being of judges. Because of the limited availability of empirical studies on this topic, research in only five countries was included.

Motivation for the study: The state of judges' well-being may affect, among others, their decision-making ability and their decorum in court.

Research approach/design and method: A scoping review was used to synthesise research evidence on the well-being of judges. Relevant literature was searched using computerised databases, covering the period from January 2008 to May 2018. Eleven studies met the inclusion criteria. Using the ATLAS.ti 8 programme for qualitative data analysis, the data were extracted from 11 articles.

Main findings: A variety of job demands, such as judges' heavy workloads and time constraints, emotional demands of their work, negative work-home interference and their safety concerns, had a negative effect on their well-being. Despite the stressors and occupational demands to which judges were subjected, some judges experienced high levels of well-being because of, inter alia, the autonomy they had over certain aspects of their work, the nature of their work and positive relationships with their colleagues.

Practical/managerial implications: Interventions should be employed to address stressors and job demands, as well as job resources that affect judges' well-being.

Contribution/value-add: This study adds to scientific knowledge vis-à-vis the well-being of judges.

Keywords: flourishing; judges; well-being; functioning; feeling.

\section{Introduction}

Subjective well-being (SWB) is defined as 'a person's cognitive and affective evaluations of his or her life' (Diener, Lucas, \& Oishi, 2002, p. 63). Subjective well-being (also referred to as happiness) consists of two components, namely a hedonic component of feeling good (emotional well-being [EWB]) and a eudemonic component of functioning well (psychological well-being [PWB] and social well-being [SWB]) (Keyes \& Annas, 2009). These collective components can investigate the flourishing or languishing of people. An individual's level of flourishing or languishing can be evaluated on Keyes' (2002) mental health continuum (MHC). Keyes and Annas (2009) define flourishing as a state in which individuals experience high levels of EWB, PWB and SWB. Languishing individuals do not have much good feeling towards life, and they also do not see themselves functioning well in life. Individuals who are neither flourishing nor languishing are regarded as being moderately mentally healthy.

Rothmann (2013) extends Keyes' MHC to the work context, where flourishing, as a multidimensional concept, includes dimensions of both feeling well and functioning well in a work setting. Emotional well-being consists of job satisfaction and a positive affect balance. Psychological well-being consists of autonomy, competence, relatedness, engagement, learning (personal growth), and meaning and purpose. Subjective well-being refers to experiences focused on social tasks that are encountered in organisations (Rothmann, 2013).

In terms of the job demands-resources (JD-R) model (Demerouti, Bakker, Nachreiner, \& Schaufeli, 2001), although judges face stringent demands, they also have various personal and organisational 
resources that may well counter the influences of demands. Job demands are the physical, psychological, organisational or social features of work that necessitate sustained cognitive and emotional exertion or capabilities and are linked to physiological and psychological costs (Bakker, Demerouti, \& Sanz-Vergel, 2014; Demerouti \& Bakker, 2011; Demerouti et al., 2001). Job resources indicate those physical, psychological, organisational or social features of work that may help to attain objectives in the workplace, decreasing job demands and stimulating personal development and advancement (Demerouti \& Bakker, 2011). Personal resources are features of an individual that are usually associated with resilience. It refers to people's sense that they have the capability to successfully manage and have an impact on their environment (Hobfoll, Johnson, Ennis, \& Jackson, 2003).

It is important that judges feel good and function optimally in their work environment, that is, they are flourishing, as they are responsible not only for the fate of litigants but also for maintaining equal justice through due processes and for upholding the constitution of their country. The state of judges' well-being, that is, whether they flourish or languish, or fall somewhere in-between on the MHC of Keyes (2002), may affect inter alia their decision-making ability and their decorum in court. When judges do not flourish because of, for example, heightened emotions and anxiety, their ability to consider relevant evidence may be negatively affected. They may also make impulsive, irrational or cynical decisions (Miller \& Richardson, 2006). When judges frequently express their frustrations, anger or impatience, and consequently, intentionally mistreat or belittle those who appear before them, they may be depicted as bullies (Richmond, 2012). Such behaviour subjects all judges to public contempt. On the other hand, when judges flourish, they experience, among others, job satisfaction, they feel optimistic and they are productive. This positive mindset is transferred to all role players in court, for example, the litigating parties, witnesses and staff members. This, in turn, has a positive effect on the public's faith in courts. Therefore, the well-being of judges will not only influence the esteem of the judiciary but also influence the public's trust and confidence in the judicial system. Research on the well-being of judges is thus of great importance.

This study focused on the themes of SWB of judges, both negative and positive, which emerged from the literature.

\section{Well-being of judges}

A judge is a public officer appointed to decide cases in a court of law (The Oxford English Dictionary). In terms of section 165(2) of the Constitution of the Republic of South Africa (1996), 'The courts are independent and subject to the Constitution and the law, which they must apply impartially and without fear, favour or prejudice'. The above-mentioned authority is applicable to judges worldwide.

Although duties of judges can vary, into some extent, from one country to another, for example, in certain countries, judges care for the well-being of jurors (Flores, Miller, Chamberlain, Richardson, \& Bornstein, 2009), their responsibilities remain generally similar. As independent decision-makers in the quest for justice, their duties include, among others, interpreting the law, assessing the evidence presented and managing how trials proceed in their courts. The judge passes sentence and imposes an appropriate penalty if a defendant was convicted of a crime. In civil cases, judges decide whether a claim is enforceable, assess damages and grant orders or some other form of relief to the plaintiff, unless a jury has been appointed (Canadian Superior Courts Judges Association, 2018). Appellate judges decide whether appeal cases were correctly decided on the facts and the law. If not, these judges can reverse a judgement and make an appropriate order. Administrative duties could include, for example, drawing up budgets for the courts and managing staff (Malone, 2018), while the judges president and deputy judges president oversee the administrative processes of the judiciary.

The transition from advocate or attorney to judge may be overwhelming and stressful. Once sworn into office, judges are subjected to public scrutiny. Because of the restrictions imposed by the Code of Judicial Conduct, they are expected to act appropriately and to maintain respectable conduct, not only in the courtroom but also in their private lives (Zimmerman, 2000). Judges may consequently feel a great deal of pressure to uphold an ideal image.

Judges work in an environment that is generally adversarial. They often experience workplace conflict (or perceived conflict) with staff, colleagues and legal practitioners, such as poorly prepared and disrespectful counsel and uncooperative defendants (Chamberlain \& Miller, 2009). Judges must frequently preside over cases and make decisions that will influence the future of an individual, a family or sometimes an entire community. The circumstances of a matter may be extremely pressing, for example, attempts to stop an urgent medical procedure. Even determining commercial disputes that will result in, for example, the unsuccessful party losing his or her home and life savings, can take their toll (Hampel, 2015). Judges' position of authority permits them to decide the destiny of others, and this can be a tremendous burden on their conscience (Resnick, Myatt, \& Marotta, 2011). When making rulings, judges must remain impartial, fair and independent, irrespective of whether they preside over a case where parties act in opposition to their values and beliefs. They must act with integrity, courtesy and professionalism.

The occupation of judges demands the ability to cope with a consistently heavy workload and intense emotional investment. Long working hours and an overabundance of cases add stress to judges' already challenging work. Consequently, some judges become workaholics (Hagen \& Bogaerts, 2014). Judges' workloads often result in them working after hours, either in their chambers or at home. Time for friends and family, recreation and even sport and cultural pursuits is severely limited, which has an adverse effect on judges' work-home balance. Moreover, after being elevated to the 
bench, judges regularly lose contact with friends, family and former colleagues (Lebovits, 2017) because of their social standing. This, in turn, results in formal and deferential behaviour. Judges suddenly acquire a new first name, 'Judge', and, consequently, often feel socially isolated (Zimmerman, 2000).

Female judges are particularly prone to stress. In addition to personal factors, they must deal with the same stressors as male judges in the execution of their duties because no exceptions in the workplace are made for some judges, irrespective of their gender (Anleu \& Mack, 2014). Female judges often face gender bias and must ward off genderbased attacks (Lebovits, 2017). According to Schroeder (2002), female judges' isolation is greater than that of their male counterparts probably because judges are still predominantly male in certain countries and/or divisions, and in some instances, there is still a lack of acceptance of female judges (Fricke \& Onwuachi-Willigt, 2012). Furthermore, women by and large continue to have primary family responsibilities, and female judges must thus balance their careers and families in ways that male judges never experience (Durant, 2004).

Many judges have significant concerns about their safety, both in and out of court, as violence and threats against judges have been on the increase, creating a sense of vulnerability and anxiety (Chamberlain \& Miller, 2009). There are numerous examples of attacks on judges. For example, in February 2005, the family of Judge Lefkof, a female senior United States district judge, was brutally murdered by a man as an act of retribution, as he blamed her rulings for many of his problems. In June 2006, a family law judge, Judge Weller, was seriously injured when he was shot through a window of his chambers in Reno, Nevada. His attacker had reportedly been disgruntled about his decisions regarding child support and maintenance (Miller \& Richardson, 2006). More recently, in 2014, the safety of Judge Lamont, a high court judge in Johannesburg, was compromised when he presided over the matter of Czech fugitive Radovan Krejčír. A knife was found in a consultation room, and the windscreen of Judge Lamont's car mysteriously cracked while he was driving. Shortly after the knife incident, the judge was also informed of a heating element from a kettle that had been discovered in a parcel given to Krejčír at the court. Security for Judge Lamont was consequently upgraded. It is evident that judges are more noticeable by the public and that they are more exposed and vulnerable than other public figures because of their office.

According to the literature, employees who sense that their job demands surpass the available resources because of, for example, emotional or physical strain, will feel incapable to manage at work (May, Gilson, \& Harter, 2004; Schaufeli \& Bakker, 2004). This can potentially cause employees to feel that they are not in control of their environment, and consequently, they will not flourish. The judiciary's work unmistakably involves an inescapable component of stress, as members experience a variety of occupational demands.
Judges are human and are thus not immune to negative feelings, such as anger, sadness and stress. The influence of stress can result in a variety of negative outcomes. Studies have shown that an imbalance between job demands and resources is a significant determinant of burnout (Demerouti et al., 2001; Schaufeli \& Bakker, 2004), and judges are vulnerable to work-related burnout (Chamberlain \& Miller, 2009) and its ensuing detrimental emotional, physical and cognitive consequences.

Mack and Anleu (2008) found that, for most judges participating in their study, the demands of being a judge were balanced by substantial sources of satisfaction. Therefore, despite the demands and stressors in their everyday work, many judges flourish; that is, they feel and function well. The nature of their work, for example, the autonomy and flexibility they have, and the quality of justice delivered, supportive interactions with their colleagues and superiors, as well as their working environment and the way in which the court functions, among other factors, enhance the well-being of judges.

Judicial service ranks among the highest status jobs and the most fulfilling ways to serve one's country (Lebovits, 2017). For many advocates and attorneys, elevation to the bench is the pinnacle of their careers, affording them opportunities to effect positive change in other people's lives (Resnick et al., 2011). They genuinely enjoy their work, and they are mostly satisfied with their work and the legal profession. This, as well as available job and personal resources, boosts their engagement, which, in turn, influences organisational commitment (Hakanen, Rodriguez-Sánchez, \& Perhoniemi, 2012).

\section{Aim of the study}

This study aimed to review qualitative and quantitative empirical studies regarding different factors that affect the well-being of judges globally and to determine what can be done to reduce the occupational stressors that result in them languishing, as well as actions that can be taken to enhance their flourishing.

Research questions:

- What documented factors, negative and positive, influence the well-being of judges worldwide?

- How do these factors have an impact on the well-being of judges?

- What interventions should be undertaken to address judges' stressors in order to advance their flourishing and prevent languishing?

\section{Research design \\ Research method}

A scoping review was chosen to synthesise research evidence (quantitative and qualitative) on the well-being of judges globally in terms of its nature, features and outcomes, and to 
represent the range of located evidence graphically. Scoping reviews are an accepted approach for mapping comprehensive themes, but as the approach is relatively new, there is no universal study definition or definitive procedure available. A scoping review is a type of research synthesis that aims to chart the nature, range and extent of the literature on a specific topic or research area. It offers an opportunity to identify important concepts, areas requiring further research as well as the nature and sources of information, to advise others for future use in, for instance, research and policymaking (Peters et al., 2015; Pham et al., 2014). It was important to review the findings of selected studies and to provide an overview of the existing evidence on the well-being of judges, regardless of its quality, as this topic has not yet been reviewed comprehensively.

Considering the aim of this systematic scoping literature review, a priori review protocol had been developed before the review itself was undertaken to predefine the objectives and methods of the scoping review and to detail the proposed plans (Peters et al., 2015).

To avoid publication bias, searches for relevant studies, including unpublished studies, were conducted without limiting outcome terms. To locate relevant studies, electronic databases, such as PsycINFO, PsycARTICLES, ResearchGate, ProQuest, NEXUS and Google Scholar, were used, and the Manager: Information Services - Vaal Triangle Campus of the North-West University was consulted. The search was performed using the following keywords: 'judges', 'judiciary', 'well-being' or 'wellbeing' or 'wellness of judges', 'wellbeing' or 'wellbeing' or 'wellness of the judiciary', 'flourishing of judges', 'flourishing of the judiciary', 'job satisfaction of judges', 'judicial stress', 'job demands of the judiciary', 'job resources of the judiciary' and 'gender differences in the judiciary'.

The researcher strived for truth by systematically documenting the research process in sufficient detail to enable the study to be replicated by others, for example, when deciding which articles to include and when creating codes and themes. Moreover, the promoter of the study verified the process to ensure that nothing was missed. This explicit approach, and the fact that multiple data sources had been used, enhanced the reliability of the findings and counters any suggestion that the study lacks methodological rigour (Mays, Roberts, \& Popay, 2001).

\section{Research procedure}

Searches for relevant studies regarding the well-being of judges were conducted using computerised online databases and performing manual searches from the reference lists of the articles and electronic journals reviewed. The literature search had resulted in a total of 124 references, but after studies were compared, seven duplicated articles were discarded.
Subsequently, a selection process ensued based on inclusion and exclusion criteria. Criteria for the inclusion of articles were as follows:

- Articles had to be published in English from January 2008 to May 2018 in peer-reviewed journals.

- Participants in the studies had to be judges.

- As limited empirical articles are available on this topic, no limitation was placed on the source of the articles.

- No limitation was placed on the type of research method used.

After the selection process, 70 more records were excluded, as they preceded the indicated period. The first author entered the remaining 47 articles into the ATLAS.ti 8 program for qualitative data analysis and assessed same for eligibility. Unfortunately, a limited number of articles were peer-reviewed. None of the searches produced empirical studies on the well-being of judges in the South African context. The promoter of the study reviewed the selection process, the selected studies and the articles tentatively included, excluded or not yet decided on. The search results were further refined to be consistent with the focus area of this study, namely judges, resulting in the exclusion of 31 more articles that concentrated on magistrates and lawyers as members of the judiciary. Lastly, five articles were excluded, as they were not based on empirical studies. Eleven studies eventually met the inclusion criteria.

Both researchers also detailed a proposed plan for presenting the results (Peters et al., 2015). The procedure followed is represented in Figure 1 (flow diagram - extracting and charting of result

Initially, the first author examined and did a comprehensive synopsis of each article according to the research objective, concepts or theories applied, citation, study design, demographic information and sample size. Special attention

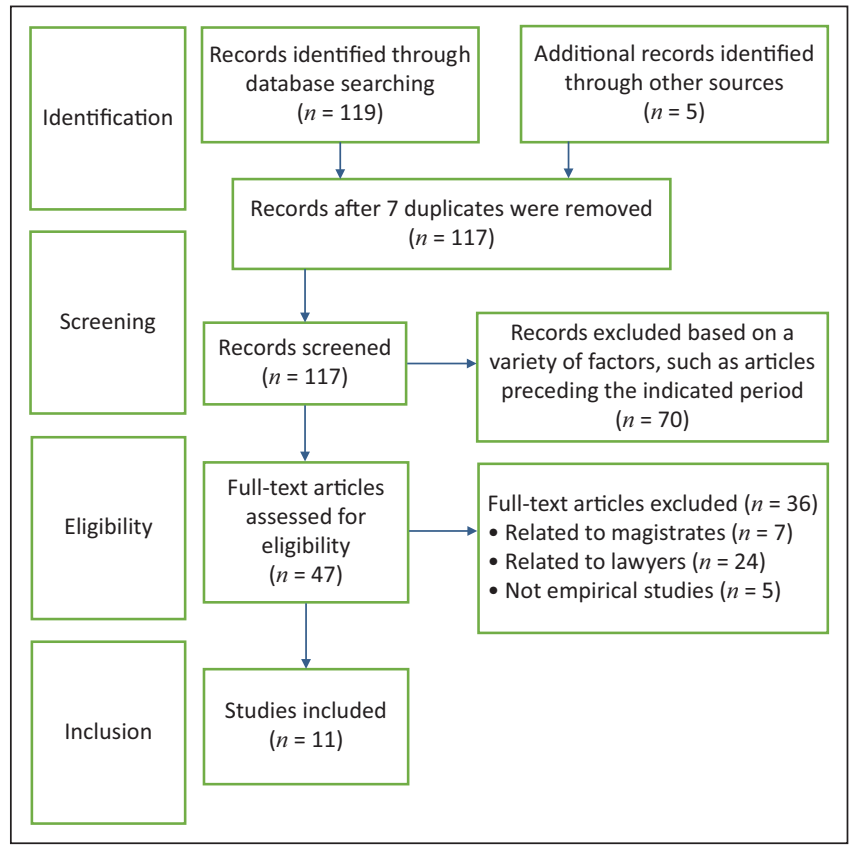

FIGURE 1: Flow diagram: extracting and charting results. 
was given to, among others, factors affecting judges' wellbeing and their occupational and personal outcomes. Thereafter, the thematic synthesis comprised three phases that overlapped to a certain extent: the free line-by-line coding of the findings of primary researches; the organisation of these 'free codes' into related areas to create 'descriptive' themes; and the development of 'analytical' themes (Thomas \& Harden, 2008). To enhance integrity, two researchers independently extracted the relevant data from the 11 articles, using the ATLAS.ti 8 program, which they then analysed independently to eliminate research bias. Firstly, both researchers independently coded the text, using codes that were created inductively to encapsulate the meaning and content of each sentence. New codes were developed, as and when needed in the process of reviewing each article. An iterative exploration of the quotations ensued in themes emerging from the codes (Tracy, 2013). The author then used the descriptive themes that had emerged from the inductive analysis of study findings to reply to the research questions, which resulted in the development of more abstract and analytical themes. The promoter of the study corroborated the themes identified by checking same against each of the articles. Thereafter the data were compiled into an Excel spreadsheet to determine the frequency of the constructs. The most frequently appearing ones were used for analysis and discussion in this study. The use of such a systematic, iterative method validated a rigorous analysis process and enhanced the credibility of the findings (Silverman, 2011).

\section{Studies reviewed}

Detailed descriptions of the 11 studies included in the review are listed in Table 1. Among these 11 articles, seven were conducted in the USA, one in Australia, one in Finland, one in Argentina and one in Switzerland.

\section{Ethical consideration}

The study received ethical clearance from the North-West University, Human and Social Sciences Research Ethics Committee. Ethical Clearance Number: NWU-HS 2017-0062.

TABLE 1: Summary of studies included.

\begin{tabular}{lll}
\hline Number & Authors & Country \\
\hline 1 & Lustig et al. (2008) & United States \\
2 & Lustig et al. (2008a) & United States
\end{tabular}

Data collection method, sample size, description of participants and objective of the research

Surveys were emailed to immigration judges via a secure website to enquire about their work environment. $N=96$. The response rate was $45.3 \%$. The mean age of the responding immigration judges was 53 years (range $35-72$ ). The study sample was $43 \%$ female and $57 \%$ male. The mean years of experience were 10 (range 1-25 years).

Surveys were emailed to immigration judges via a secure website to investigate their working conditions, as well as stress and burnout they might experience. $N=96$. The response rate was $45.3 \%$. The mean age of the responding immigration judges was 53 years (range 35-72). The study sample was $43 \%$ female and $57 \%$ male. The mean years of experience were 10 (range 1-25 years). A total of $59(61.4 \%)$ of the initial 96 respondents provided narrative comments about 'anything else that would help explain the occupational challenges faced by Immigration Judges'.

\begin{tabular}{lll}
\hline 3 & Kohen (2008) & Argentina \\
\hline 4 & Flores et al. (2009) & United States \\
\hline 5 & $\begin{array}{l}\text { Chamberlain and } \\
\text { Miller (2009) }\end{array}$ & United States \\
& $\begin{array}{l}\text { Chase and Hora } \\
\text { (2009) }\end{array}$ & United States \\
\hline 6 &
\end{tabular}

This exploratory study aimed to analyse gender differences in the values and attitudes of family judges in Buenos Aires. Because of the absence of relevant knowledge and data, the researcher had to start from a shallow base, building a substantial body of existing and new information to supply her research with the necessary theoretical, socio-historical and institutional context. The conceptual framework provided by feminist legal theory was analysed by giving specific attention to the ways legal feminism had explained the situation of women in the legal profession.

Exploratory study: Secure online surveys were sent to a convenience sample of American trial judges to determine their perceptions of jury stress and their own experiences with stress and safety issues. $N=163$. The respondents included 95 perceptions of jury stress and their own experiences with stress and safety issues. $N=$
$(58 \%)$ men, $65(40 \%)$ women and three $(2 \%)$ who chose not to indicate their gender.

In-depth case study: Semi-structured interviews were conducted to determine whether and how three occupational experiences, that is, STS, safety concerns and burnout, affected judges' performance of their occupational duties. $N=9$. The respondents were all Caucasians, of whom two were women and seven men. Their tenure on the bench varied from a few months to over 15 years. All of them were close (physically and professionally) to the shooting of family court judge Chuck Weller.

Three different surveys were used to compare problem-solving court judges with traditional court judges. The first survey compared drug treatment judges with traditional family law court judges. The second survey added a group of unified family court judges who worked in assignments more specifically designed on the problem-solving model. The third survey added a group of traditional criminal court judges. $N=355$, consisting of 113 problem-solving judges (drug court and unified family court) and 242 traditional judges (criminal and family court). There were 69 drug court judges, of whom $74 \%$ were male and $26 \%$ female; 44 unified family court judges, of whom $71 \%$ were male and $29 \%$ female; 85 family court judges, of whom $66 \%$ were male and $34 \%$ female; and 157 traditional criminal court judges, of whom $73 \%$ were male and $27 \%$ female. All the

judges were more or less of a similar age, varying from 51 to 53. Their tenure in their profession varied from 9 to 16 years. who was shot by a litigant in a divorce case over which he had presided. Questions were intended to measure the principles of constructivist self-development theory (CSDT), which were specifically designed to determine whether the shooting had affected the judges' safety, esteem, intimacy, trust and control needs. $N=9$, of whom six were men and three women. They had been employed in their current positions from a few months to more than 15 years. They were interviewed between 4 and 8 weeks after the shooting. and 8 w

$8 \quad$ Norris, Commons, United States Miller, Adams and Gutheil (2011)

A pilot study relating to judges in Massachusetts was conducted to establish the extent of their perceived satisfaction in an objective, empirical way, via a Rasch analysis. Anonymous surveys. $N=44$, of whom 30 were probate court judges and 14 superior court judges. Most respondents were male (28, or $63.6 \%$ ) as opposed to female $(16$, or $36.4 \%)$, and their mean age was 56.4 years. Respondents had served as judges for an average of 9.36 years.

\begin{tabular}{lll}
9 & $\begin{array}{l}\text { Hakanen et al. } \\
(2012)\end{array}$ & Finland \\
\hline 10 & $\begin{array}{l}\text { Ludewig and } \\
\text { Lallave (2013) }\end{array}$ & Switzerland
\end{tabular}

A postal questionnaire survey was sent to judges working in Finnish district courts, courts of appeal and the supreme court as part of a national well-being study introduced by the Supreme Court of Finland. $N=550$, which yielded a response rate of $78 \%$. Of the participants, $55.5 \%$ were male and $44.5 \%$ were female. Their mean age was 53.5 years, and the average number of years employed in their present tasks was 11.4 years.

A mixed method was used to determine the psychological experiences of Swiss male and female judges. Qualitative phase $N=111$, of whom 31 were female and male judges, and 80 were other members of the legal profession. The number of participants in the quantitative phase, which was designed from an analysis of the initial interviews, was 243 , all professionally trained women and men from 50 courts in German-speaking Switzerland.

Note: See the full reference list of the article, Rossouw, E., \& Rothmann, S. (2020). Well-being of judges: A review of quantitative and qualitative studies. SA Journal of Industrial Psychology/SA Tydskrif vir Bedryfsielkunde, 46(0), a1759. https://doi. org/10.4102/sajip.v46i0.1759, for more information.

STS, secondary traumatic stress. 


\section{Results}

Table 2 provides a summary of the themes that were identified from the 11 studies that were chosen for the purpose of this study.

From the review of the articles, it was evident that not all judges experienced the same job demands and sources of stress, as these varied according to, among other things, their gender, their country's political and economic position, the courts in which they worked and the type of cases over which they presided. The following is a discussion of the factors reported in the above-mentioned articles that had either a negative or positive influence on the well-being of judges.

\section{Occupational stressors}

\section{Work pressure and time constraints}

Judges constitute a specific occupational group characterised by overwhelming caseloads, long working hours, considerable responsibility and distorted borders between work and leisure time (Hakanen et al., 2012). It is not uncommon for judges to remain in their chambers after hours or to take work home in an attempt to keep up with their crushing workloads under tremendous time pressure. Judges from the USA, Finland, Switzerland and Australia reported work pressure and time constraints, and it thus seems like a fairly universal phenomenon. A total of $98.6 \%$ of Swiss judges, in the study conducted by Ludewig and Lallave (2013), mentioned time pressure as the most significant job demand, which resulted in them experiencing conflict between the quality and quantity of work. Similarly, in their study relating to immigration judges in the USA, Lustig et al. (2008a, 2008b) found that, in addition to emotional demands, they faced overwhelming, complex workloads, which had to be dealt with in insufficient time.

\section{Emotional demands}

Flores et al. (2009) found that the highest levels of judicial stress stemmed from cases concerning crimes against

TABLE 2: Summary of themes.

\begin{tabular}{|c|c|c|}
\hline Number & Most common reported themes & Article \\
\hline 1 & $\begin{array}{l}\text { Occupational stressors: } \\
\text { - Work pressure and time pressure } \\
\text { - Emotional demands } \\
\text { - Safety concerns } \\
\text { - Negative work-life balance } \\
\text { - Gender bias } \\
\text { - Gender differences and similarities } \\
\text { - Decision-making } \\
\text { - Inadequate resources and support }\end{array}$ & 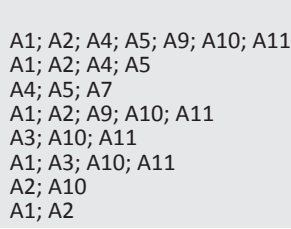 \\
\hline 2 & $\begin{array}{l}\text { Impact of stress and trauma: } \\
\text { - Burnout } \\
\text { - Secondary traumatic stress (STS) } \\
\text { - Trauma - changes in esteem needs } \\
\text { - Emotional and physical manifestation } \\
\text { of overwork or stress }\end{array}$ & $\begin{array}{l}A 1 ; A 2 ; A 4 ; A 5 ; A 6 \\
A 1 ; A 2 ; A 5 \\
A 4 ; A 7 \\
A 1 ; A 2 ; A 4 ; A 5 ; A 9\end{array}$ \\
\hline 3 & Interventions to reduce stress & $A 1 ; A 2 ; A 4 ; A 5 ; A 9$ \\
\hline 4 & $\begin{array}{l}\text { General feeling of well-being: } \\
\text { - Job satisfaction } \\
\text { - Job characteristics } \\
\text { - Positive co-worker relationships } \\
\text { - Engagement versus workaholism }\end{array}$ & $\begin{array}{l}\text { A2; A6; A8; A9; A11 } \\
\text { A6; A9; A10 } \\
\text { A8 } \\
\text { A9 }\end{array}$ \\
\hline
\end{tabular}

children, violent crimes and sexual offences. Complicated asylum cases are referred to immigration judges, who must decide on the fate of asylum seekers (Lustig et al., 2008b). They hear some repugnant stories and are repeatedly exposed to a wide variety of human cruelty and misery (Lustig et al., 2008a). Findings from this review indicate that especially judges from the USA reported emotional demands.

\section{Safety concerns}

Another frequently reported stressor is safety concerns as a result of violence and threats against judges, which result in them experiencing a sense of vulnerability and anxiety (Chamberlain \& Miller, 2009; Flores et al., 2009). Being subjected to violent deeds or other stressors can have a negative effect on both judges' professional and personal lives (Miller \& Richardson, 2006). Once again, this review reveals that mainly USA judges are concerned about their safety.

\section{Negative work-home interference}

Judges do not separate themselves easily from emotions and difficult cases when leaving the office. Being so involved in their work, whether physically, emotionally or cognitively, obviously cuts into the free time that they could have spent with family and friends or pursuing non-work-related activities. Negative work-home interference was reported by judges from the USA, Finland, Switzerland and Australia. In their research regarding Swiss judges, Ludewig and Lallave (2013) found that $90 \%$ of the judges reported difficulties affecting their private life. Although both male and female judges in Switzerland struggled to maintain work-life balance, Swiss female judges rated 'feeling that their private life hinders their professional goals' considerably higher than their male counterparts. The mean for women was 2.52, while it was 1.87 for men (Ludewig \& Lallave, 2013).

\section{Gender bias}

Female judges not only report higher levels of concern about personal safety than their male counterparts (Flores et al., 2009), but they also continue to experience subtle forms of gender discrimination because judging has remained a traditionally male-dominated profession (Anleu \& Mack, 2014; Ludewig \& Lallave, 2013). In the study conducted by Ludewig and Lallave (2013), 51.5\% of female judges, as opposed to $5.2 \%$ of male judges in Switzerland, reported that they experience gender discrimination. In professions where more men than women are appointed, women's satisfaction with their work tends to be lower (Lundquist, 2008). Conversely, Kohen (2008) found that despite their dual role, being the primary caretaker at home and having to fulfil their occupational duties, judges in Argentina generally viewed bias as something that had essentially occurred in the past and has disappeared with the establishment of a new and more transparent system for judges to be selected and elevated to the bench, via the 'Consejo de la Magistratura'. Likewise, in Switzerland, the system may have improved, as female judges with more 
than 9 years of work experience reported more gender discrimination than those with fewer than 9 years' experience (Ludewig \& Lallave, 2013).

\section{Gender differences and similarities}

It is evident that male and female judges experience their work and their response to trauma differently. According to Anleu and Mack (2014), in order to understand female's experiences of judicial office, one must disentangle the effects of, among other things, age (generation) and time on the bench (cohort). Female judges are generally younger (average age 52 compared to 59 for men) and more recently elevated to the bench ( 9 years compared to 10.6 for their male colleagues). The differences in age and time on the bench between males and females are therefore significant. Kohen (2008) found that the breaks in the female judges' careers, because of disruptions on account of maternity and taking care of children, certainly had a negative impact on their prospects of professional progression. Ludewig and Lallave (2013) determined that both male and female judges experienced stress when their work interfered with their family life. However, female judges felt that the stress in family life could hinder their professional goals. Furthermore, they felt more obliged to cope with multiple tasks and assume the ultimate social responsibility for the family, household and child caring, because of the traditional parental role distribution where women continue to have primary family responsibilities (Ludewig \& Lallave, 2013). In their study, Lustig et al. (2008a) found that female judges were more susceptible to trauma and burnout than male judges. Although they could not explain the difference, it is possible that female judges, generally originating from human rights or private practice backgrounds, have greater concern about the physical and EWB of asylum seekers, as opposed to male judges, emanating from a prosecution background. Another explanation put forward by Lustig et al. (2008a) is that female judges are either more conscious of, or more disposed to relate subjective feelings of distress compared to male judges.

\section{Decision-making}

Judges engage in decision-making under potentially stressful conditions daily. A total of $98.4 \%$ of Swiss judges reported difficulties in decision-making (Ludewig \& Lallave, 2013).

\section{Inadequate resources and support}

In addition to their crushing workloads and time constraints, judges often face persistently inadequate resources and an unsupportive infrastructure, which contribute to their high levels of stress (Lustig et al., 2008a, 2008b). It is thus not surprising that they feel 'burnt out'.

Other than the demands noted above, judges experience stress stemming from, among others, lengthy and tedious trials, trial disruptions and conflict among colleagues and/ or court employees (Chamberlain \& Miller, 2009; Flores et al., 2009).

\section{Impact of stress and trauma}

Judges' occupational stress is manifested in physical and emotional problems, such as sleep disturbances, muscle tension, eating problems, hypertension, diabetes, irritability, burnout (Flores et al., 2009) and secondary traumatic stress (STS) (Chamberlain \& Miller, 2009).

Following a traumatic event, individual judges can experience alterations in their psychological needs vis-à-vis their safety, esteem, intimacy, trust and control (Miller et al., 2010). Deviations in personal esteem needs can, for instance, result in judges doubting their abilities and choices. Chamberlain and Miller (2009) found that nearly half of the judges in the USA who had participated in their study expressed a fear that violence could affect their decisions. Several reported that they, from time to time, had reason to believe that offenders might be dangerous or might try to take revenge. They thus had to be cautious not to allow their trepidation to influence their judgements. Constructivist self-development theory (CSDT) provides a valuable theoretical basis to understand the responses that judges have subsequent to a violent workplace event, as it suggests that traumatic incidents can disrupt a person's cognitive schemas (Miller et al., 2010). The results of the study by Miller et al. (2010) conducted in the USA indicate that judges' reactions were largely in keeping with CSDT. When asked how their lives had changed since the 2006 shooting of a family court judge, Judge Weller, everyone interviewed exhibited some level of distortion in their safety, esteem, intimacy, trust and control needs. Distortions of safety and esteem needs were the most prevailing alterations in cognitive schemas.

Judges who deal with family and criminal cases are particularly prone to vicarious trauma (VT) and compassion fatigue (CF). Vicarious trauma or CF, also labelled STS, refers to the cumulative effect suffered by people who work with trauma, such as abuse, rape, torture and murder, as part of everyday work (Chamberlain \& Miller, 2009). Secondary traumatic stress, which was termed the 'cost of caring' by Charles Figley in 1995, includes symptoms similar to that of Post-traumatic Stress Disorder (PTSD) (Lustig et al., 2008b). In their study, Lustig et al. (2008a) determined that US immigration judges experienced significant symptoms of STS, scoring means of 2.0, 2.3 and 2.4 out of 5 on subscales for intrusion, avoidance and arousal symptoms, respectively. Female judges reported more STS compared to male judges. Female judges' total burnout mean was also higher than that of their male counterparts. Lustig et al. (2008a), furthermore, found that, in comparison with other professionals, immigration judges, particularly female judges, were even more burnt out than doctors, who cared for very sick patients, and prison wardens, who dealt with the most aberrant people.

As discussed in some of the articles under review, judges' work-related burnout can lead to emotional exhaustion, cynicism, depersonalisation and reduced personal accomplishment (Miller \& Richardson, 2006), as well as anger, anxiety and depression. Burnout may also result in a 
low self-esteem, negative mindsets towards work, and impoverished relationships, such as lack of empathy, temper outbursts or an egocentric exhibition of self-confidence (Lebovits, 2017; Miller \& Richardson, 2006). If a burnt-out judge is impatient and petulant, it is probable that the perception of the judicial system will be negative (Chase \& Hora, 2009). Some prevalent physical reactions to burn out comprise headaches, insomnia, hypertension, weight gain and substance abuse (Jaffe, Crooks, Dunford-Jackson, \& Town, 2003; Lebovits, 2017).

From the above discussion, it is apparent that judges' negative work experiences - that is, performing their work in an environment that is often adversarial, and where they generally receive very limited positive feedback or support regarding their decisions - have a negative bearing on their well-being, and judges tend to languish.

\section{Interventions to reduce stress}

Several interventions to reduce stress have been proposed. In the first instance, the crushing workload of judges can be reduced by increasing the number of judges and appointing more support staff (Lustig et al., 2008a). Judges should undergo training to recognise symptoms of STS in themselves (Chamberlain \& Miller, 2009). Male judges, in particular, should change their attitude regarding the reporting of their stress and safety concerns (Flores et al., 2009) to facilitate therapeutic measures, such as post-trial debriefings following difficult trials. Judges should take breaks from work, such as sabbaticals or short (2-4 days) respites, to minimise workrelated burnout (Chamberlain \& Miller, 2009; Hakenen et al., 2012). Moreover, procedural changes, such as properly equipped courthouses to stop acts of violence, and policies to reduce stressors should be implemented (Chamberlain \& Miller, 2009; Flores et al., 2009).

\section{General feeling of well-being}

On the positive side, this review revealed that, despite their occupational demands and stress, several judges felt good and functioned at a high level, that is, they flourished. The following factors were noted as playing a positive role in their well-being.

\section{Job satisfaction}

Numerous judges are satisfied with the inherent and external elements of their work, and they feel positive when at work. This is substantiated by the study regarding job satisfaction of the judiciary in Australia, conducted by Anleu and Mack (2014). Nine out of 10 (92\%) judicial officers were satisfied, including very satisfied, with their work $(88 \%$ women and $94 \%$ men). The pilot study of Norris et al. (2011) regarding job satisfaction of judges in Massachusetts displayed similar results. They found that, on a scale of 1 ('dissatisfied') to 6 ('completely satisfied'), the lion's share of the sample appraised their satisfaction as 5 or 6 . For the whole sample, the mean satisfaction level of $5.02(\mathrm{SD}=0.762)$ was significantly higher than the value of 1 or 'dissatisfied': $t(43)=35.011, p=0.004$. Both probate court and superior court judges were equally satisfied. It is fascinating that there was a positive relationship between caseloads and satisfaction, which suggests that those judges with excessive caseloads were just as satisfied as those with smaller caseloads (Norris et al., 2011). Regarding the effects of the nature of cases, Norris et al. (2011) found that the social class of courtroom participants was positively related to general satisfaction.

The type of court in which judges serve, its procedures and the way it functions have a major effect on the job satisfaction of judges. Chase and Hora (2009) compared judicial satisfaction, specifically relating to effectiveness, attitude towards parties and positive effects of case allocations, between those US judges appointed to problem-solving courts, such as unified family and drug treatment courts, and judges in other more conventional assignments, such as criminal and family law courts. Judges in the problemsolving courts (unified family and drug treatment courts) scored significantly higher on all three scales than those who were not (criminal and traditional family court), with the drug treatment court judges scoring the highest. This probably relates to the fact that the unified family and drug treatment courts have generally espoused the principles of therapeutic jurisprudence (Chase \& Hora, 2009). The job satisfaction experienced by problem-solving court judges stemmed from several factors:

- They believed that courts should assist the accused to address the problems that caused them to be there.

- They were more likely to observe positive changes in the accused.

- They were also more likely to have faith in the accused's motivation to change and were capable to do so.

- They felt that the accused respected them.

- They generally thought that the accused appreciated the assistance they received.

The problem-solving court judges thus felt happy with their assignments, which they believed had a positive effect on their emotions (Chase \& Hora, 2009). When judges feel optimistic and productive, their mindsets are transferred to litigants, staff members and counsel. Their job satisfaction therefore predicts the satisfaction of litigants and has a considerable impact on the public's faith in courts.

\section{Job characteristics}

Autonomy contributes significantly to the well-being of judges. Compared with attorneys and doctors, Swiss judges enjoy greater autonomy and have greater responsibility for part-time work, and their work is more compatible with family life. They consequently rank their satisfaction with their work very high. Ludewig and Lallawe (2013) found the mean for female judges to be 8.22 and 8.37 for male judges. Despite some discrimination that still exists, the well-being of Argentinian female judges, especially family court judges, is enhanced by the stability of their work and their shorter working day because they find it easier to combine their careers with their family responsibilities, as opposed to being 
employed at large law firms (Kohen, 2008). The quality of justice dispensed also affects judges' psychological and SWB. When judges accept and appreciate themselves and others and when they are proud of their work, they gain more confidence (Chase \& Hora, 2009), and they find purpose and meaning in their work. Judges will then be inclined to engage in their work, which Schaufeli, Salanova, González-Romá and Bakker (2002) describe as a positive, fulfilling, workrelated state of mind, characterised by vigour (investing energy and being physically occupied with a task), dedication (being connected and committed to the work and co-workers) and absorption (being involved and attentive at work).

\section{Positive co-worker relations}

Although judges work independently, they do have opportunities to interact with their colleagues, for example, during teatime. Despite their challenging work environment because of the adversarial judicial system, judges build supportive networks and positive relationships among colleagues or friends (Norris et al., 2011). When individuals feel that they are accepted by their colleagues, they believe that they are in the right place, and it has a significant impact on their meaningfulness at work (Steger \& Dik, 2009).

\section{Engagement}

Individuals who are engaged in their work, that is, who experience a positive, fulfilling, work-related state of mind that is marked by vigour, dedication and absorption, do not resent feeling fatigued because they take pleasure in their work from which they acquire a sense of achievement (Schaufeli \& Bakker, 2007). In contrast, workaholics have the propensity to be obsessed with their work, and to work extraordinarily hard and compulsively (Schaufeli, Taris, \& Van Rhenen, 2008).

In their investigation regarding the similarities and differences between work engagement and workaholism among Finnish judges, Hakanen et al. (2012) found that engagement had beneficial and positive relations with individual outcomes (positively associated with basic evaluations of the self, such as locus of control, self-esteem and self-efficacy), work-family outcomes (positively related to WF+ and FW+ and negatively to WF- and FW-) and organisational outcomes (positively associated with job resources, such as fairness, trust and supportive organisational climate and commitment, while negatively associated with turnover intention). Nevertheless, even though engaged judges enjoy working, they are also overworked because of their boundaryless work and long working hours. They should thus make sure that they recover sufficiently, for example, by detaching from work, to remain engaged (Hakanen et al., 2012).

\section{Discussion}

This study aimed to investigate the negative and positive factors affecting the well-being of judges globally and to determine what actions can be taken to enhance their flourishing. It is important to note that judges' situations differ from country to country, and therefore, factors affecting their well-being also vary. Through the amalgamation of the findings, the following constructs were identified as being prominent stressors for judges: working long hours in order to cope with a consistently heavy workload; experiencing emotional demands because of exposure to gruesome evidence or human misery, and making decisions affecting other people's lives; experiencing negative work-home interference, especially female judges; having inadequate resources and support; and being concerned about safety and violence against judges and their families. Gender bias and discrimination were also reported by some female judges, but it seemed that this inclination had subsided over the years.

As evidenced in the research under review, specific stressors and job demands are mostly the same for all judges, irrespective of their geographical location, the type of court or the work they do, while other stressors relate to a specific group of judges. Some female judges, for example, find it stressful to balance their work-home life, as they are expected to do the same work as their male counterparts, while they continue to carry the primary family responsibilities.

Because of their severe workloads and long hours to complete the work timeously, judges often must function at a breakneck pace, with hardly enough time to take their eyes off the case before them. Consequently, judges often become workaholics, as they are propelled by an intense preoccupation with their job (Hagen \& Bogaerts, 2014; Hakanen et al., 2012). This, as well as the stress associated with their work, results in workrelated burnout and STS. Judges suffering from burnout and STS experience an assortment of negative physical, emotional and cognitive consequences. Heightened levels of stress and burnout can cause judges to lose concentration, gross delay in the delivery of reserved judgements, impairment of their decision-making abilities and intolerance of others (Lustig et al., 2008a; Miller \& Flores, 2007). These outcomes can potentially have a negative effect for litigants whose fate rests in the hands of judges. Furthermore, if judges experience moderate or severe distortions in any of their CSDT needs, that is, their safety, esteem, intimacy, trust and control needs, such distortions are likely to impact their functioning and can, eventually, have an adverse effect on the administration of justice (Miller et al., 2010).

It is thus vital that we comprehend and account for judges' stressful experiences, as they have the potential to have a negative effect on their personal lives, and to hinder them to perform their duties to the best of their ability (Chamberlain \& Miller, 2009). Being a judge is a privilege, and it should bring judges happiness (Lebovits, 2017). Judges whose stresses threaten to keep them from that enjoyment should get help, for example, attend wellness programmes or take breaks. Resources should be made available to decrease or negate judges' job demands and, consequently, to support them to attain their work objectives, to stimulate personal 
development and to result in them feeling good and, ultimately, functioning optimally.

From the findings, it became apparent that, despite being faced with stressors and job demands, some judges encountered substantial sources of satisfaction in the execution of their duties. Their work can have significant, or even life-changing, effects on the lives of others. Because of the significance of their actions and decisions, they are engaged in their work and do not resent working hard and long hours. The tasks of judges, which are diverse and intellectually challenging, and which can contribute to a better society, together with, among other things, positive coworker relations, promote their feelings of enjoyment and enthusiasm about their work.

This scoping review examined the lived world of judges and factors influencing their welfare. In the process, it also raised the question of what could be done to further promote their well-being in order for them to flourish.

Reflecting on the research endeavour, the author realised that a scoping review is a lengthy process and that the researcher is not in control of the quality of the content of the primary studies. The researcher did not only depend on the studies found via electronic data searches, but also reference lists of available articles were perused and the services of the Manager: Information Services of the North-West University were elicited to obtain more resources. Although some media sources such as newspaper articles were perused to enrich the researcher's knowledge, these were not included as they did meet the inclusion criteria.

\section{Limitations of the study}

Various study limitations should be noted. Firstly, studies from only five countries were included in this review, as limited empirical research regarding the well-being of judges has been performed and because there is a relative lack of data regarding judges because judicial officers have been perceived as a 'difficult population' for social and behavioural science research. This perceived 'difficulty' derives from, among others, their time constraints, eminent status, professional inaccessibility, assumed resentment or reservation to participate and concerns about the confidentiality of responses (Mack \& Anleu, 2008). Secondly, being a scoping review, this study did not appraise the rigour or quality of evidence in the primary research reports. Lastly, although the authors pursued best practice throughout the research process, the trustworthiness of this study could have been improved if external auditors or research participants validated the findings.

\section{Implications and recommendations for practice}

The following interventions that focus on the well-being of judges could be a point of departure in addressing judges' occupational stressors and demands:
- Initiatives should be undertaken to help to reduce stress arising from the heavy workload of judges. Caseloads should be managed, for example, by monitoring the case mix, the volume of work, the amount of judgement writing time and the number of reserved judgements. More judges could be appointed to meet exploding caseload burdens, especially in immigration courts in the USA. Some of the non-judicial tasks, which take up a large proportion of judges' time, or which they frequently undertake, could be allocated to non-judicial court staff, which could reduce costs and increase flexibility. It would, however, be necessary to ensure that the quality of decision-making is not compromised and that resources are available to meet the additional demands placed on non-judicial staff.

- Anxiety originating from occupational responsibilities could be alleviated by taking breaks from work. Having a break from the constant stream of work could help prevent the long-term damage of burnout and STS. Even only 1 day off to engage in a favourite hobby or sporting activity could help a judge return to the bench feeling refreshed and relaxed. Occasionally, longer term sabbaticals should also be encouraged to allow judges to get away for a few weeks or months. Research conducted by Resnick et al. (2011) revealed that some judges were of the view that a good way to spend their sabbatical was to attend judicial training programmes, work with relief organisations, offer training to other less experienced colleagues, exchange positions with judges in other states to experience regional differences, and to travel.

- With regard to violence against and safety concerns of judges, multiple precautionary measures should be implemented. Chamberlain and Miller (2009) propose that trained professionals who can recognise flaws in safety measures should inspect court buildings regularly, and their advice should be adhered to in order to make sure that employees and the public are as safe as possible. Moreover, judges should be given relevant information, training opportunities and skills, as well as devices to protect themselves. Personal safety programmes can, for example, contribute to judges being more vigilant and able to defend themselves when attacked. Judges should increase security at their personal residences.

- To make the judicial workplace more sensitive to females' needs and to enhance the job satisfaction of female judges, greater flexibility regarding hours (both during the regular workweek and after hours) and more recognition of family responsibilities are required in policies and procedures. Incidentally, a number of jurisdictions in Australia have made part-time appointment and jobsharing available to judges (Anleu \& Mack, 2009).

\section{Recommendations for future research}

Future research should determine the prevalence and range of different stressors that judges face. Research could, for example, focus on the factors that cause the most stress for 
judges, the category of judges who are most at risk, the way these occupational stressors affect judges' personal lives and the likely effects stress has on a judge's work performance and general well-being. It is important, though, to utilise instruments specifically designed to assess stressors that are exclusive to judges' occupation.

Future studies should be more representative - composed of judges of more countries, including developing countries such as South Africa where no such studies have been conducted (SA ePublications; NEXUS) - as this will enhance our understanding of the way in which courts function and are staffed. This could, in turn, result in processes and/or measurements being put in place that would increase judicial satisfaction.

Future research could also focus on the development of intervention strategies to support judges who suffer from high stress levels. These strategies should be specifically personalised to alleviate the distinct stressors that judges encounter. Giving guidance to newly appointed judges in orientating themselves at their new place of work - for example, alerting them to the need to be finely attuned to the etiquette rules, showing them where to park and where the library and other research facilities are - will probably reduce their stress. Intervention strategies could also include training of newly appointed judges on how to formulate judgements, which was recognised as a great source of stress during a workshop for advocates on the subject of acting judges held in Rivonia, South Africa, in May 2015 (Johannesburg Society of Advocates 2015).

Finally, female judges' experience in the workplace needs further investigation. This could include research on measures to be implemented on:

- ways to increase the number of women in the judiciary, for example, through mentoring, training and greater involvement in politics

- ways to enhance their job satisfaction by being more sensitive to the fact that they must deal with the same stressors male judges do, while having to balance their careers and families

- ways to prevent gender bias.

\section{Conclusion}

In this study, sources of occupational stress of judges include, among others, specific job characteristics, the type of matters over which they preside, safety concerns and gender differences. Given their positions, their work must continue despite their circumstances. To cope with all their obligations, judges often put their well-being on the back burner. Accumulating stress and suppressing emotions have damaging effects on a judge's psychological and physical well-being, as well as cognitive and decision-making skills, especially when difficult decisions must be made quickly. Despite the demands placed on judges, many find their work satisfying because of, among others, their job characteristics: having autonomy over some aspects of their work and the quality of justice delivered, positive co-worker relationships and the fact that their decisions can potentially make a significant difference in the lives of others. It is vital that judges feel good and function optimally, as these factors are predictors of litigant satisfaction and have a significant influence on the public's confidence in the courts. Actual efforts should thus be made to combat judges' occupational stressors and to enhance their well-being.

\section{Acknowledgements Competing interests}

The authors have declared that no competing interests exist.

\section{Authors' contributions}

All authors contributed equally to this work.

\section{Funding information}

This research received no specific grant from any funding agency in the public, commercial or not-for-profit sectors.

\section{Data availability statement}

Data sharing is not applicable to this article as no new data were created or analysed in this study.

\section{Disclaimer}

The views and opinions expressed in this article are those of the authors and do not necessarily reflect the official policy or position of any affiliated agency of the authors.

\section{References}

Anleu, S.R., \& Mack, K. (2009). Gender, judging and job satisfaction. Female Lega Studies, 17, 79-99. https://doi.org/10.1007/s10691-009-9111-z

Anleu, S.R., \& Mack, K. (2014). Job satisfaction in the judiciary. Work, Employment and Society, 28(5), 683-701. https://doi.org/10.1177/0950017013500111

Bakker, A.B., Demerouti, E., \& Sanz-Vergel, A.I. (2014). Burnout and work engagement: The JD-R approach. Annual Review of Organizational Psychology and Organizational Behavior, 1(1), 389-411. https://doi.org/10.1146/annurevorgpsych-031413-091235

Canadian Superior Courts Judges Association. (2018). The role of the judge. Retrieved from http://www.cscja.ca/judges/the-role-of-the-judge/

Chamberlain, J., \& Miller, M.K. (2009). Evidence of secondary traumatic stress, safety concerns, and burnout among a homogeneous group of judges in a single jurisdiction. The Journal of the American Academy of Psychiatry and the Law, $37(2), 214-224$

Chase, D., \& Hora, P.F. (2009). The best seat in the house: The court assignment and judicial satisfaction. Family Court Review, 47(2), 209-238. https://doi. org/10.1111/j.1744-1617.2009.01250.x

Constitution of the Republic of South Africa. (1996). Chapter 8. Courts and administration of justice. Section 165. Butterworths Statues of South Africa (2)2012, Part 4 Constitutional Law (p. 92). Johannesburg: LexisNexis, Pty Ltd.

Demerouti, E., \& Bakker, A.B. (2011). The Job Demands-Resources model: Challenges for future research. SA Journal of Industrial Psychology/SA Tydskrif vir Bedryfsielkunde, 37(2), Art. \#974, 9 pages. https://doi.org/10.4102/sajip. v37i2.974

Demerouti, E., Bakker, A.B., Nachreiner, F., \& Schaufeli, W.B. (2001). The job demandsresources model of burnout. Journal of Applied Psychology, 86(3), 499-512. https://doi.org/10.1037/0021-9010.86.3.499

Diener, E., Lucas, R.E., \& Oishi, S. (2002). Subjective well-being. The science of happiness and life satisfaction. In C.R. Snyder \& S.J. Lopez (Eds.), Handbook of positive psychology (pp. 187-194). Oxford: Oxford University Press.

Durant, L.V. (2004). Gender bias and the legal profession: A discussion of why there are still so few women on the bench. University of Maryland Law Journal of Race, Religion, Gender and Class, 4(1), Art. 6, 181-205. 
Flores, D.M., Miller, M.K., Chamberlain, J., Richardson, J.T., \& Bornstein, B.H. (2009). Judges' perspectives of stress and safety in the courtroom: An exploratory study. Court Review: The Journal of the American Judges Association, 293(3), 76-89.

Fricke, A., \& Onwuachi-Willigt, A. (2012). Do female 'firsts' still matter? Why they do for female judges of color. Michigan State Law Review, 1529(4), 1529-1554.

Hagen, T., \& Bogaerts, S. (2014). Work pressure and sickness absenteeism among judges. Psychiatry, Psychology and Law, 21(1), 92-111. https://doi.org/10.1080/ 13218719.2013.790003

Hakanen, J., Rodriguez-Sánchez, A.M., \& Perhoniemi, R. (2012). Too good to be true: Similarities and differences between engagement and workaholism among Finnish judges. Ciencia \& Trabajo, 14, 72-80.

Hampel, F. (2015). From stress to resilience. Law Institute Journal, Mental Health 89(9), 33-35.

Hobfoll, S.E., Johnson, R.J., Ennis, N., \& Jackson, A.P. (2003). Resources loss, resource gain, and emotional outcomes among inner city women. Journal of Personality and Social Psychology, 84(3), 632-643. https://doi.org/10.1037/0022-3514.84.3.632

Jaffe, P.G., Crooks, C.V., Dunford-Jackson, B.L., \& Town, M. (2003). Vicarious trauma in judges: The personal challenge of dispensing justice. Juvenile and Family Court Journal, Fall, 1-9. Retrieved from http://www.crvawc.ca/documents/Vicarious Trauma_Judges_Fall03.pdf

Johannesburg Society of Advocates. (2015). Workshop for advocates on the subject of acting judges. 29-31 May. Rivonia, Johannesburg, South Africa: Liliesleaf Farm.

Keyes, C.L.M. (2002). The mental health continuum: From languishing to flourishing in life. Journal of Health and Social Behaviour, 43(2), 207-222. https://doi. org $/ 10.2307 / 3090197$

Keyes, C.L.M., \& Annas, J. (2009). Feeling good and functioning well: Distinctive concepts in ancient philosophy and contemporary science. Journal of Positive Psychology, 4(3), 197-201. https://doi.org/10.1080/17439760902844228

Kohen, B. (2008). Family judges in the city of Buenos Aires: A view from within International Journal of the Legal Profession, 15(1-2), 111-122. https://doi. org/10.1080/09695950802439775

Lebovits, G. (2017). Judicial wellness: The ups and downs of sitting New York judges. New York State Bar Association, 89(5), 10-22.

Ludewig, R., \& Lallave, J. (2013). Professional stress, discrimination and coping strategies: Similarities and differences between female and male judges in Switzerland. In U. Schultz \& G. Shaw (Eds.), Gender and judging (pp. 233-252) Oxford: Hart Publishing.

Lundquist, J.H. (2008.) Ethnic and gender satisfaction in the military: The effect of a meritocratic institution. American Sociological Review, 73(3), 477-496. https:// doi.org/10.1177/000312240807300306

Lustig, S.L., Delucchi, K., Tennakoon, L., Kaul, B., Marks, D., \& Slavin, D. (2008a) Burnout and stress among United States immigration judges. Bender's Immigration Bulletin, 13, 22-30.

Lustig, S.L., Karnik, N., Delucchi, K., Tennakoon, L., Kaul, B., Marks, D., \& Slavin, D. (2008b). Inside the judges' chambers: Narrative responses from the national association of immigration judges stress and burnout survey. Georgetown Immigration Law Journal, 23(57), 57-83.

Mack, K., \& Anleu, S.R. (2008). The national survey of Australian judges: An overview of findings. Journal of Judicial Administration, 18(1), 5-21.

Malone, M. (2018, December 31). What are a judge's duties? Retrieved from https:// careertrend.com/judges-duties-2351.html

May, D.R., Gilson, R.L., \& Harter, L.M. (2004). The psychological conditions of meaningfulness, safety and availability and the engagement of the human spirit at work. Journal of Occupational and Organizational Psychology, 77(1), 11-37. https://doi.org/10.1348/096317904322915892

Mays, N., Roberts, E., \& Popay, J. (2001). Synthesising research evidence. In N. Fulop P. Allen, A. Clarke \& N. Black (Eds.), Studying the organisation and delivery of health services (pp. 188-220). London: Routledge.
Miller, M.K., Flores, D.M. (2007). Addressing the problem of courtroom stress. Judicature, 91(2), 60-69.

Miller, K.M., Flores, D.M., \& Pitcher, B.J. (2010). Using constructivist selfdevelopment theory to understand judges' reaction to a courthouse shooting: An exploratory study. Psychiatry, Psychology and Law, 17(1), 121-138. https://doi. org/10.1080/13218710902930309

Miller, M.K., \& Richardson, J.T. (2006). A model of causes and effects of judicial stress. Judges' Journal, 45(4), 20-23.

Norris, D.M., Commons, M.L., Miller, P.M., Adams, K.M., \& Gutheil, T.G. (2011). A pilot study of job satisfaction in Massachusetts judges. Journal of Psychiatry \& Law, 39(2), 321-337. https://doi.org/10.1177/009318531103900208

Peters, M.D.J., Godfrey, C.M., Khalil, H., McInerney, P., Parker, D., \& Soares, C.B. (2015). Guidance for conducting systematic scoping reviews. International Journal of Evidence-based Healthcare, 13(3), 141-146. https://doi.org/10.1097/ XEB.0000000000000050

Pham, M.T., Rajić, A., Greig, J.D., Sargeant, J.M., Papadopoulos, A., \& McEwen S.A. (2014). A scoping review of scoping reviews: Advancing the approach and
enhancing the consistency. Research Synthesis Methods, 5(4), 371-385. https:// enhancing the consistency.
doi.org/10.1002/jrsm.1123

Resnick, A., Myatt, K.A., \& Marotta, PV. (2011). Surviving bench stress. Family Court Review, 49(3), 610-617. https://doi.org/10.1111/j.1744-1617.2011.01396.x

Richmond, D.R. (2012). Bullies on the bench. Louisiana Law Review, 72(2), 325-360. Retrieved from http://digitalcommons.law.lsu.edu/lalrev/vol72/iss2/1

Rothmann, S. (2013). Flourishing at work: A Southern African perspective. In M.P. Wissing (Ed.), Cross-cultural advancements in positive psychology (pp. 123-151). New York, NY: Springer-Verlag.

Sabinet African Electronic Publications (SA ePublications) [Database]. Retrieved from http://reference.sabinet.co.za.nwulib.nwu.ac.za/sa_epublications

Schaufeli, W., \& Bakker, A. (2007). Burnout en bevlogenheid [Burnout and work engagement]. In W. Schaufeli \& A. Bakker (Eds.), De psychologie van arbeid en gezondheid (pp. 341-358). Houten: Bohn Stafleu van Loghum.

Schaufeli, W., Salanova, M., González-Romá, V., \& Bakker, A. (2002). The measurement of engagement and burnout: A two sample confirmatory factor analytic approach. Journal of Happiness Studies, 3, 71-92. https://doi.org/10.1023/A:1015630930326

Schaufeli, W.B., \& Bakker, A.B. (2004). Job demands, job resources and their relationship with burnout and engagement: A multi-sample study. Journal of Organizational Behavior, 25(3), 293-315. https://doi.org/10.1002/job.248

Schaufeli, W.B., Taris, T.W., \& Van Rhenen, W. (2008). Workaholism, burnout, and work engagement: Three of a kind or three different kinds of employee wellbeing? Applied Psychology: An International Review, 57(2), 173-203. https:// doi.org/10.1111/j.1464-0597.2007.00285.x

Schroeder, M.M. (2002). Judging with a difference. Yale Journal of Law \& Feminism 14(2), Article 7. Retrieved from http://digitalcommons.law.yale.edu/vjlf/vol14/ iss $2 / 7$

Silverman, D. (2011). Qualitative research: Issues of theory, method and practice (3rd edn.). London: Sage.

Steger, M.F., \& Dik, B.J. (2009). If one is looking for meaning in life, does it help to find meaning in work? Applied Psychology: Health and Well-being, 1(3), 303-320. https://doi.org/10.1111/j.1758-0854.2009.01018.x

The Oxford English Dictionary. Judge. Retrieved from https://en.oxforddictionaries. com/definition/judge

Thomas, J., \& Harden, A. (2008). Methods for the thematic synthesis of qualitative research in systematic reviews. BMC Medical Research Methodology, 8(45), 10. https://doi.org/10.1186/1471-2288-8-45

Tracy, S.J. (2013). Qualitative research methods: Collecting evidence, crafting analysis, communicating impact. West Sussex: Wiley-Blackwell.

Zimmerman, I.M. (2000). Isolation in the judicial career. Court Review - The Journal of the American Judges Association, 36(4), 4-8. 